\title{
EL MODELO DE RESPONSABILIDAD DEL GOBIERNO EN LA CONSTITUCIÓN DE 1978 O JUGAR A LAS SIETE Y MEDIA
}

ESTHER GONZÁLEZ-HERNÁNDEZ 
SUMARIO

I. 1978: UNA CONSTITUCIÓN, SIN DUDA, MERITORIA. II. DE LA RESPONSABILIDAD PENAL A LA RESPONSABILIDAD POLÍTICA. III. LA RESPONSABILIDAD GUBERNAMENTAL EN LA CONSTITUCIÓN ESPAÑOLA DE 1978: A. El artículo 102 y la responsabilidad penal. B. La responsabilidad política a través de la «censura»: a. Una cuestión de confianza en el olvido, b. La moción de censura: tres veces y ninguna dimisión. IV. EL FUTURO QUE ESTÁ POR LLEGAR. BIBLIOGRAFÍA. 


\title{
EL MODELO DE RESPONSABILIDAD DEL GOBIERNO EN LA CONSTITUCIÓN DE 1978 O JUGAR A LAS SIETE Y MEDIA
}

\author{
ESTHER GONZÁLEZ-HERNÁNDEZ \\ Profesora Titular de Derecho Constitucional \\ Universidad Rey Juan Carlos ${ }^{1}$
}

\section{1978: UNA CONSTITUCIÓN, SIN DUDA, MERITORIA}

En 1840, un francés que respondía al nombre de Teófilo Gautier, mientras visitaba Irún, expresaba un funesto maleficio al contemplar una plancha de yeso blanco con la inscripción «Plaza de la Constitución»: «Una Constitución en España es una pellada de yeso sobre granito ${ }^{2}$. La frase ha sido ampliamente utilizada por los constitucionalistas para expresar uno de los grandes males de nuestra historia reciente: una preocupante inestabilidad constitucional, traducida en la promulgación de un significativo número de Constituciones. La vigente Constitución de 29 de diciembre de 1978 ha venido, no obstante, a acabar con este maleficio, otorgándonos ya cuarenta años de vigencia, que esperamos se prolongue hasta convertirse en la Constitución más longeva y estable de nuestra historia constitucional.

Por tanto, a los constitucionalistas corresponde ponerla en valor, pues, sin duda, estamos ante un texto de honda significación y resonancia para nuestra historia más reciente, si bien a costa, quizás, de que acuse más que otros Textos constitucionales,

\footnotetext{
${ }^{1}$ Esther González Hernández. Profesora Titular de Derecho Constitucional. Facultad de Ciencias Jurídicas y Sociales. Universidad Rey Juan Carlos. Paseo de los Artilleros s/n. 28032 Vicálvaro Madrid. Email: esther.gonzalez@urjc.es. Código orcid.org/0000-0001-7203-5032. La presente investigación se ha desarrollado en el marco del Programa S2015/HUM-3466 NEW TRUST-CM. Programa interuniversitario en Cultura de la Legalidad, financiado por la Comunidad de Madrid y el Fondo Social Europeo, IP: José María Sauca, dentro del Grupo GI FIIE/URJC. FCCJJ y SS sobre Fortalecimiento institucional y estructura ética, IP: Esther González Hernández.

${ }^{2}$ García Escudero, J. M. ${ }^{a}$, «Cortes constituyentes», Ya, 5 de junio de 1977, Fundación Juan March, Archivo Linz de la Transición española (URL: http://linz.march.es/Documento.asp?Reg=r-7326, fecha de consulta: 12 de septiembre de 2017).
} 
el llamado «juego de las siete y media». Expliquemos esta curiosa paradoja a que se refería don Manuel Fraga, en la sesión de 16 de mayo de 1978 de la Comisión de Asuntos Constitucionales y Libertades Públicas: «las Constituciones acusan mucho más todavía el famoso juego de las siete y media, el quedarse o el pasarse» ${ }^{3}$. Por lo menos, así parece en lo que se refiere a la regulación de los instrumentos constitucionales de exigencia de responsabilidad gubernamental en que pareciese que prefirió plantarse a pasarse.

Mientras el Texto de 1978 parte del firme convencimiento, de que los gobernantes deben dar cuentas y respuesta de su actuación, el sistema que diseña es manifiestamente mejorable. Así lo ha vuelto a poner de manifiesto la última crisis económico-financiera en que ha aflorado un creciente sentimiento de descontento entre la ciudadanía y la opinión pública que cree que el Gobierno ni responde ni rinde cuentas. Nuestra democracia se ha visto sometida a una "prueba de estress» que no ha hecho sino aflorar una de las cuestiones a mejorar de nuestro Texto constitucional, que arrastra ciertas deficiencias en el cumplimiento del principio de responsabilidad de los poderes públicos, magistralmente consagrado en su art. 9.3: «La Constitución garantiza el principio de legalidad, la jerarquía normativa, la publicidad de las normas, la irretroactividad de las disposiciones sancionadoras no favorables o restrictivas de derechos individuales, la seguridad jurídica, la responsabilidad y la interdicción de la arbitrariedad de los poderes públicos».

Procede, por tanto, que nos detengamos (siquiera brevemente) en explicar cómo se materializó este principio históricamente, pues primero fue la responsabilidad penal, luego el control parlamentario y, tiempo después, llegó la responsabilidad política.

\section{DE LA RESPONSABILIDAD PENAL A LA RESPONSABILIDAD POLÍTICA}

Afirmaba McIlwain, con razón, que «al constitucionalismo le es consustancial la idea de límite, se entienda esta en términos jurídicos, implicando la necesidad de que los poderes públicos se adecuen a la Ley Fundamental so pena de la nulidad de sus actuaciones controlables jurisdiccionalmente, o se haga en términos políticos, de modo que los poderes asuman las diferentes tareas del Estado controlándose entre sí. En Inglaterra la idea de límite que primero se afirma es la jurídica» ${ }^{4}$. De aquí que no deba extrañar que las fórmulas constitucionales de exigencia de responsabilidad política nazcan en Reino Unido como evolución histórica y casi inevitable, me atrevería a decir, del famoso impeachment. Si bien el proceso de evolución y

\footnotetext{
${ }^{3}$ Cortes Generales, Constitución española .Trabajos parlamentarios, t. I, Cortes Generales, Madrid, 1981, p. 877.

4 Mcilwainm, Ch. H., Constitucionalismo antiguo y moderno, Centro de Estudios Políticos y Constitucionales, Madrid, 2016, p. 15.
} 
gestación de una responsabilidad menos criminal a más política fue, además de arduo, complicado y tortuoso, lento, singularmente lento. Así no se puede hablar de ella como tal, hasta el siglo XIX, a pesar de los precedentes ingleses, poco armados y en mantillas del XVIII.

A pesar de su lenta evolución, en Reino Unido se siguió una línea, más o menos, continua y sostenida de fortalecimiento del Parlamento en detrimento del poder del Rey. A diferencia del continente, en las islas nunca se olvidó el principio de limitación del poder regio lo que, a la larga, no podía derivar en otra cuestión que en la exigencia de responsabilidad. Es así como empieza a desarrollarse una teoría que sitúa en el control del Gabinete ministerial, la clave del buen gobierno y que supone, pues, la construcción de los modernos sistemas de accountability desde la Ilustración y pasando por Monstesquieu y los padres fundadores de la democracia americana ${ }^{5}$.

Por tanto, el principio general de control del gobierno es un producto de la civilización de la política ${ }^{6}$, porque la responsabilidad política surge de la necesidad de crear un sistema de sucesión de los diferentes gobiernos, sin que estos estuviesen, irremediablemente, destinados a la muerte o la prisión, como había sido lo usual en Gran Bretaña hasta los tiempos del Parlamento Largo y la Grand Remonstrance de 22 de noviembre de $1641^{7}$. No obstante, hubo que esperar algún tiempo más para que surgiese el principio de responsabilidad solidaria del Gobierno, concretamente hasta el gobierno de Lord North, primer Ministro de Jorge III. El 8 de marzo de 1782, los whigs presentaron una moción de censura colectiva (vote of want of confidence) que sostenía que la Cámara no podía mantener por más tiempo la confianza en los ministros. Esta moción fue derrotada por una escasa diferencia de dos votos, pero fue nuevamente presentada unos días después, y Lord North, seguro de que saldría adelante, dimitió y con él todos los miembros de su Gabinete menos Lord Thurlow. Empezó, por tanto, a gestarse, pues, el convencimiento de que el Parlamento podía imponer al Ejecutivo la obligación de dimitir bajo determinadas circunstancias.

5 Villoria Mendieta, M., «Transparencia y rendición de cuentas», en Desafección política y regeneración democrática en la España actual: diagnósticos y propuestas, F. Llera Ramo (coord.), Centro de Estudios Políticos y Constitucionales, Madrid, 2016, p. 283.

${ }^{6}$ García Morillo, J., «La responsabilidad política», Temas Clave de la Razón Práctica, n. 45 (septiembre), 1994, p. 32.

7 A partir de estas fechas, fue costumbre solicitar al Rey que emplease solo a consejeros, ministros o embajadores que contasen también con la confianza del Parlamento. Por ello, no debe sorprender que durante el largo Gobierno Walpole (1720-1742) se manifestasen varios intentos de organizar una oposición capaz de derribarle. Hasta el siguiente Parlamento no fue lo suficientemente compacta para librar la batalla que le llevase a su cese. Concretamente, el 13 de febrero de 1741 se presentaron diversas mociones "para la remoción de Walpole y de los consejeros de su Majestad para siempre», que, si bien fueron derrotadas, manifestaban una clara mayoría parlamentaria contraria a Walpole. Así, los días 28 de enero y 2 de febrero de 1742, el Primer Ministro perdió dos votaciones que le obligaron a dimitir al constatar que una parte de los Whigs, encabezados por William Pitt, se habían aliado contra él y no contaba con la confianza del Parlamento. 
Se instala, así, en el discurso político la idea de que el Gobierno está obligado a responder políticamente del desarrollo de sus funciones constitucionales de dirección político-ejecutiva, lo que supone un mecanismo de afectación de un valor a una conducta gubernamental ${ }^{8}$, por más que la acción política se caracterice por un amplio margen de libertad. Por tanto, a diferencia de la responsabilidad penal, esta no implica inculpación, acción u omisión contraria al Derecho, sino una ponderación de que el arbitrio que se concede al político gobernante, ha sido utilizado con acierto y oportunidad. Esta nace directamente de unos hechos que se consideran inadecuados o ineficaces desde el punto de vista político y que, se cree, le impiden la continuidad en el ejercicio de un cargo, pero que en ningún caso son ilícitos o ilegales. Por ello, la reparación o respuesta será la remoción del cargo, esto es, la obligación de dimitir. El cese se presenta, así, como la sanción más adecuada, porque, como dice Bentham, los empleados públicos «cuando más tienen que perder en bienes u honores, perdiendo sus empleos, tanto mejor se les puede sujetar»?.

La aplicación de la responsabilidad política no es otra cosa, dicho con simplicidad, que expresar al Gobierno en el Parlamento: vuestras medidas no nos convencen, vuestras razones y argumentos para justificar su benignidad no nos persuaden, vuestro criterio es, a nuestro parecer, erróneo y he aquí los hechos en los que basamos nuestra disconformidad. Ciertamente, las circunstancias que la determinan son más inciertas que en la responsabilidad penal, y quizás, por esta inicial indefinición, ha sido víctima de una especie de «maldición» que durante tiempo la ha relegado a los confines del Derecho; a esas zonas obscuras, donde las miradas recelosas le negaron cualquier atisbo de luz y donde los espíritus renuncian a disipar las tinieblas que la situaban en los confines de lo jurídico. Por ello, necesitaron materializarse en una serie de vías o cauces que el Derecho Constitucional fue desarrollado, con mayor o menor acierto, a través, fundamentalmente, de la retirada de la confianza parlamentaria por la fórmula de la «censura».

Es así como surgen las fórmulas parlamentarias de exigencia de responsabilidad política que primeramente se manifiestan bajo cierta indefinición en una serie de desordenadas e improvisadas «censuras». En el continente europeo del siglo XIX ganó la idea de evitar un Ejecutivo fuerte, por el recuerdo reciente de los monarcas absolutos. La balanza se inclinó a favor de la superioridad de la Asamblea frente al Poder ejecutivo hasta bien avanzada la III República francesa, pues la Asamblea legislativa podía exigir responsabilidad política al Gobierno bajo cualquier pretexto y en cualquier momento. Se trataba de una exigencia de responsabilidad constante que no estaba sometida a formalidad alguna que pudiera constreñirla. Pero la necesidad de evitar las lamentables consecuencias que este sistema producía en términos de inestabilidad gubernamental aconsejaron que, poco a poco, se fuesen estableciendo una serie de requisitos para poder presentar estas «censuras». V. gr.: la exigencia de la

\footnotetext{
8 Segur, P., La responsabilité politique, Presses Universitaire de France, París, 1996, p. 17.

9 Bentham, J., Tratados de Legislación Civil y Penal, Editora Nacional, Madrid, 1981, p. 356.
} 
mayoría absoluta para su aprobación, la necesidad de un número mínimo de diputados para su presentación, el establecimiento de un período de enfriamiento entre su depósito y su debate, el transcurso de un cierto plazo desde la votación de la anterior, etcétera. Estos nuevos requisitos son los propios de la conocida como responsabilidad política racionalizada, que se impuso a partir de la Primera Guerra Mundial y se tradujo en la restricción de la posibilidad de interponer cualquier moción de censura, en cualquier momento y por cualquier motivo.

La censura al Gobierno, es decir, la exigencia de responsabilidad quedó sometida a ciertas condiciones, que fueron, sucesivamente, recogidas en diferentes Constituciones europeas, como la Constitución de Weimar de 1919, la Constitución austriaca de 1920 y la española de 1931. Limitaciones que, después de la Segunda Guerra Mundial, fueron creciendo y armando sistemas de «censura constructiva» como el de la Ley Fundamental de Bonn de 1949, que posteriormente fue la acogida por la Constitución española de 29 de diciembre de 1978, con la esperanza de equilibrar una teórica superioridad de la Asamblea legislativa en aras de cierta estabilidad del Gobierno. Se trataba, así, de evitar las mociones puramente negativas, que pretendía la dimisión del Presidente del Gobierno pero sin la formación de un nuevo Ejecutivo. Por ello, en las mociones de censura constructiva se requiere que las propuestas de censura del Gobierno, vayan acompañadas de un candidato a la Presidencia, para que su aprobación suponga la otorgación de la necesaria confianza para que este sea investido como nuevo Presidente.

Ahora bien, conviene no olvidar que la responsabilidad penal siguió encontrando un hueco en los Textos constitucionales. Así, las Constituciones continuaron, por lo general, regulando ambos tipos, gratificando al Ejecutivo con especiales jurisdicciones que iban desde los sistemas legislativos puros en que la Cámara Baja acusaba y a la Alta correspondía el juicio; a mixtos en que el juicio se atribuía a un órgano judicial elevado, desde el más alto de la organización judicial hasta la jurisdicción constitucional; o, incluso, tribunales especiales creados ad hoc. Por ello, cuando se habla de responsabilidad gubernamental en el ámbito constitucional habrá que hacer referencia, cuanto menos (sino más), a dos posibles tipos: la jurídico-penal y la política.

\section{LA RESPONSABILIDAD GUBERNAMENTAL EN LA CONSTITUCIÓN ESPAÑOLA DE 1978}

La Constitución española de 29 de diciembre de 1978 se refiere en varias ocasiones al concepto de «responsabilidad del Gobierno». Concretamente en los artículos: 9.3, 98, 102, 108, 113. Ya hemos dicho que en el art. 9.3 CE se contiene el principio constitucional general, mientras que en los siguientes regula los diferentes tipos de responsabilidad a que puede verse sometido el Gobierno. Así, en el 102 alude a un especial régimen de responsabilidad penal de los miembros del Gobierno, mientras que el 98, 108 y 113, fundamentalmente, regulan su responsabilidad política. Por 
tanto, la Constitución alude a diferentes formas y procedimientos por los que el Gobierno está obligado a responder en función de la naturaleza del acto que origina esa obligación de dar respuesta; naturaleza del acto que, a su vez, determina una diferente sanción. En resumen, la Constitución afirma el principio general de responsabilidad de los poderes públicos a través de los siguientes tipos:

1. La responsabilidad jurídica, que se refleja en la afirmación constitucional de la responsabilidad administrativa del Gobierno (art. 103 y 106 CE) y en un especial régimen de responsabilidad penal de sus miembros. Ahora bien, debe tenerse presente que en la Constitución de 1978, a diferencia de la Constitución de 1931, no regula a un especial régimen de responsabilidad civil de los miembros del Gobierno ${ }^{10}$.

2. La responsabilidad política, que, si bien se afirma es solidaria (art. 108), se manifiesta de un modo individual a través de la censura al presidente del Gobierno (art. 113) y la reprobación de los ministros (art. 98.2).

\section{A. El artículo 102 CE y la responsabilidad penal}

Dice el artículo 102 de nuestra Norma Fundamental:

«1.La responsabilidad criminal del Presidente y los demás miembros del Gobierno será exigible, en su caso, ante la Sala de lo Penal del Tribunal Supremo.

2. Si la acusación fuere por traición o por cualquier delito contra la seguridad del Estado en el ejercicio de sus funciones, sólo podrá ser planteada por iniciativa

${ }_{10}$ Sin embargo, en el artículo 56.2 de la Ley Orgánica del Poder Judicial se señala: «La Sala de lo Civil del Tribunal Supremo conocerá de las demandas de responsabilidad civil por hechos realizados en el ejercicio de su cargo, dirigidas contra el Presidente del Gobierno, los Presidentes del Congreso y del Senado...». Por tanto, la responsabilidad civil de los miembros del Gobierno no tendría otra particularidad que la relativa al fuero especial. Sin embargo, al integrarse los ministros en la Administración hay que ponerla en relación con la responsabilidad administrativa, pues el Ministro, en tanto en cuanto realiza funciones públicas, estará sujeto a una responsabilidad de tipo administrativo, cuando su acción u omisión haya causado un daño a los administrados que debe ser resarcido. Por ello, la responsabilidad civil de los ministros del art. 56.2 LOPJ se configura como una responsabilidad prima facie residual, porque sólo puede exigirse cuando los ministros actúen como simples particulares. En consecuencia, siempre que se trate de miembros del equipo gubernamental en el ejercicio de funciones públicas, la responsabilidad civil cede ante la responsabilidad administrativa. El problema, no obstante, se plantea en relación con el presidente del Gobierno, porque al no realizar funciones administrativas, no se sabe en qué medida le afecta esta responsabilidad civil del art. 56.2 LOPJ. Por tanto, su responsabilidad administrativa será asumida por el ministro/a de la Presidencia. Por ello, el artículo 56.2 LOPJ cuando atribuye a la Sala de lo Civil del Tribunal Supremo la competencia para enjuiciar su responsabilidad civil en el ejercicio de sus funciones, debe ser entendido como el último eslabón de esa tendencia que pretende dar una cobertura total al ciudadano, dado que éste no podría acudir a la Jurisdicción contencioso-administrativa. Sea como fuere no parece tan clara la justificación de este aforamiento como en la esfera de lo criminal. No parece que tenga mucho sentido, porque una eventual responsabilidad civil no es óbice para el normal desarrollo de las funciones ejecutivas. 
de la cuarta parte de los miembros del Congreso, y con la aprobación de la mayoría absoluta del mismo.

3. La prerrogativa real de gracia no será aplicable a ninguno de los supuestos del presente artículo».

Asume, pues, un especial régimen de exigencia de responsabilidad penal de los miembros del Ejecutivo, que se traduce en que estos cuentan con el especial status procesal del aforamiento o juicio ante la Sala de lo Penal del Tribunal Supremo, mientras ocupen el cargo. Una vez cesado en el desempeño del mismo, pasa a ser enjuiciado por la Jurisdicción ordinaria.

La cobertura del art. 102.1 CE es completa ya se trate de delitos cometidos en el ejercicio de su cargo o en el supuesto de comisión de actos delictivos no referentes al ejercicio de sus funciones, pero siempre que sigan ostentando la condición de miembros del Gobierno ${ }^{11}$. Nuestra Constitución se ha inclinado, así, por un sistema judicial puro, aunque sea con la especialidad del fuero privilegiado del Tribunal Supremo. Por tanto estamos una responsabilidad netamente criminal que obedece a estrictos criterios de tipicidad, causalidad y punibilidad, aunque con la especialidad, típicamente patria, que supone este fuero especial que obedece a razones de tipo histórico ${ }^{12}$.

Afortunadamente, el art. $102 \mathrm{CE}$ nunca se ha puesto en práctica, lo que no significa que la cuestión de la responsabilidad penal de los ministros haya sido pacífica, ni mucho menos. En realidad, contamos con varios procedimientos judiciales, un juicio ante el Tribunal Supremo, dos sentencias condenatorias (de momento), y un vergonzante rosario de imputaciones, si bien ni uno solo como consecuencia de la aplicación del art. 102 CE. La única ocasión en que un ministro fue juzgado por el Tribunal Supremo lo fue por su condición de diputado, pues ya no ostentaba función ejecutiva alguna. Se trata, bien es sabido de la condena del ex-ministro de Interior, José Barrionuevo, en el conocido como «Caso GAL» que, en realidad, englobó varios procesos. El que terminó con la condena de este ex-ministro y del secretario de Estado para la Seguridad, Rafael Vera, arrancó del sumario matriz 1/88, en el que, en 1990, se impuso pena de prisión a los policías Michel Domínguez y José Amedo, por el secuestro de Segundo Marey ${ }^{13}$. Tras su reapertura, el juez instructor, siguiendo la

11 Recuérdese que el art. 1.2 de la Ley 50/1997, de 20 de noviembre de Organización, competencias y funcionamiento del Gobierno señala que: «El Gobierno se compone del Presidente, del Vicepresidente o Vicepresidentes, en su caso, y de los Ministros», cuestión esta ampliamente debatida en los años previos a la aprobación de esta norma.

12 Sobre esta cuestión puede consultarse el artículo de mi autoría: «Aforamiento ante el Tribunal Supremo y responsabilidad de los empleados públicos: la diferente separación de poderes en los orígenes del constitucionalismo", Revista General de Derecho Público Comparado (Iustel), núm. 21, julio, 2017 URL: http://www.iustel.com/v2/revistas/detalle_revista.asp?id_noticia =418909\&d=1, fecha de consulta: 12 de septiembre de 2017). También de mi autoría: La responsabilidad penal del Gobierno, Centro de Estudios Políticos y Constitucionales, Madrid, 2002.

${ }_{13}$ El secuestro de Segundo Marey tuvo lugar en 4 de diciembre de 1983 en Hendaya. Fue liberado diez días después, pero el caso volvió a la opinión pública en 1994 cuando el juez de la Audiencia Nacional, Baltasar Garzón, reabre el sumario, tras nueva declaración del policía José Amedo, en la que implica a altos 
técnica del árbol probatorio, vio indicios de culpabilidad de otros altos cargos del Gobierno socialista. Por ello, en julio de 1995 remitió a la Secretaria de Causas Especiales del Tribunal Supremo un informe en el que afirmaba la existencia de indicios racionales de que el ex-ministro de Interior, José Barrionuevo, a la sazón diputado, habría incurrido en delito de pertenencia a banda armada y de malversación de caudales públicos. Así, tras la concesión del suplicatorio por el Congreso de los Diputados el 23 de noviembre de 1995, se hizo efectivo el procesamiento de Barrionuevo el 24 de enero de 1996, por los delitos de detención ilegal con condición para la liberación del secuestrado, pertenencia a banda armada y malversación de caudales públicos. Finalmente, la sentencia de 29 de julio de 1998 condena a José Barrionuevo, ex-ministro de Interior, a diez años de prisión y doce años de inhabilitación por el secuestro de Segundo Marey por los delitos de detención ilegal y malversación ${ }^{14}$.

Poco después tuvo lugar el juicio del «caso de los fondos reservados» en que ni hubo sentencia condenatoria ni tampoco se aplicó el art. $102 \mathrm{CE}$, porque los imputados, los ex-ministros de Interior José Barrionuevo y José Luis Corcuera, al haber perdido su condición de aforados fueron juzgados por la Sección 5. ${ }^{a}$ de la Audiencia Provincial de Madrid por posible delito de malversación de fondos públicos, por la sospecha de utilización fraudulenta de las partidas presupuestarias de fondos reservados asignadas al Ministerio de Interior. El centro de las imputaciones contra los dos

cargos del Ministerio de Interior, entre ellos el ex-ministro José Barrionuevo, como copartícipes, en grado de dirección, en la puesta en marcha de la banda terrorista GAL. A esta declaración le sucede un rosario de detenciones: Julián Sancristobal, ex director de la Seguridad del Estado; Francisco Saiz y Julio Hierro, inspectores de policía; Juan de Justo, secretario de Rafael Vera, ex secretario de Estado para la defensa y Ricardo García Damborenea, ex secretario general del PSOE en Vizcaya, que implica directamente al ex-presidente del Gobierno, Felipe González: «El Presidente estaba enterado de esta estrategia diseñada por políticos; yo mismo hablé con él varias veces sobre el tema». Naturalmente González lo niega. En este momento, el proceso entra en su punto álgido al vislumbrar la posibilidad de que el ex-presidente Felipe González sea llamado a declarar como imputado, a pesar de que el 29 de abril de 1996, el juez instructor Eduardo Moner, desestimase esta posibilidad. Se plantean sendos recursos de apelación, basándose en las referencias directas de Ricardo García Damborenea, Julián Sancristobal y Luis Roldán, que son desestimados el 4 de noviembre de 1996, al entender el Tribunal Supremo que las susodichas declaraciones carecían de la suficiente credibilidad.

14 El Tribunal Supremo, sin embargo no aceptó el delito de creación y pertenencia a banda armada al considerar que los GAL ni eran grupo estable, ni crearon alarma social. Rafael Vera es condenado a diez años de prisión y doce de inhabilitación por idénticos ilícitos. El 21 de agosto de 1998, se presenta ante el registro del Tribunal Constitucional recurso de amparo de Rafael Vera y José Barrionuevo firmado por el ex-presidente Felipe González, al considerar vulnerado su derecho a un juicio con todas las garantías y su derecho a la presunción de inocencia , que no impide el inmediato ingreso en prisión de los acusados porque, según reiterada jurisprudencia del Tribunal Constitucional, por lo elevado de las penas privativas de libertad no procede su suspensión temporal. El ingreso en prisión tiene lugar el 24 de septiembre. Poco tiempo después, ante el indulto parcial del Gobierno Aznar, la pena les es reducida a menos de cinco años, con lo que procedía su puesta en libertad en tanto no fuese decidido el recurso de amparo. Finalmente, el 16 de marzo de 2001 el Tribunal Constitucional ratificó la condena impuesta por el Tribunal Supremo al desestimar los recursos de amparo interpuestos por los diferentes condenados del caso «Marey», por 10 votos a favor y un único voto particular, en contra. 
ex-ministros se basaban en que habían consentido que en el Ministerio de Interior se repartieran «sobre-sueldos» millonarios entre varios altos cargos y de haberse enriquecido personalmente con ese dinero, pero fueron absueltos ${ }^{15}$. La segunda sentencia condenatoria hubo de esperar a 2015 en que la Audiencia Provincial de Palma de Mallorca condenó al ex-ministro de Medio Ambiente, Jaume Matas, en una de las piezas procesales del conocido como «Caso Palma Arena», iniciando ese rosario de «imputaciones» de ex-ministros que sigue en aumento con la reciente condición de «investigado» del ex-ministro de Justicia, Alberto Ruíz-Gallardón en el «Caso Lezo». La lista de ex-miembros del Ejecutivo es tan larga como preocupantemente es que todos lo sean por delitos que tienen que ver con lo económico. A saber: la que fuera ministra de Fomento, Magdalena Álvarez, investigada por delitos de malversación y prevaricación; Manuel Chaves, ex-vicepresidente de Política Territorial y ministro de Política Territorial y Administración Pública, por prevaricación en el «caso de los ERES»; Rodrigo Rato, ex-vicepresidente del Gobierno de España y ministro de Economía, por cinco delitos fiscales, corrupción entre particulares y blanqueo de capitales, etc. Una lista que perfectamente podría ampliarse en los últimos meses. Por no hablar de una nueva modalidad, la de responsable a título lucrativo de Ana Mato, ex-ministra de Sanidad, en el «caso Gurtel». No hablemos ya de los Ejecutivos autonómicos y, en concreto, del catalán tras los acontecimientos de septiembre y octubre del pasado 2017.

Procede una última precisión respecto del apartado 2 del art. 102. CE, que acoge el viejo impeachment anglosajón, al asumir, en parte, el sistema legislativo en la determinación de las responsabilidades criminales especiales del Ejecutivo. Así, atribuye al Congreso de los Diputados un último y único vestigio de la antigua función jurisdiccional de las Cortes $^{16}$, si bien el juicio estricto sigue siendo competencia de la Sala de lo Penal del Tribunal Supremo. Se trata, pues, de un precepto que contempla la lamentable posibilidad de que un miembro del Gobierno utilice esta posición con una finalidad claramente subversora del orden constitucional, cometiendo delitos de traición o contra la seguridad del Estado. Por tanto, el apartado 2. ${ }^{\circ}$ del artículo 102 CE regula un tipo especializante, que exige que la iniciativa de acusación se presente por el Congreso de los Diputados, a modo de lo que técnicamente se denomina condición de procedibilidad o perseguibilidad ${ }^{17}$, o autorización para procesar judicialmente a un miembro del Gobierno que hubiere cometido delito de traición o contra

${ }^{15}$ Coincidió también en el tiempo el intento de procesamiento de Josep Piqué, ministro de Industria y portavoz del primer Gobierno de José María Aznar y posteriormente ministro de Asuntos Exteriores durante el segundo Ejecutivo popular, por presuntos delitos de alzamientos de bienes y apropiación indebida, en la investigación, que sobre la suspensión de pagos de Ercros, llevaba a cabo el Juzgado de Instrucción n. 5 de Barcelona y sobre la venta de la compañía Ertoil en la Audiencia Nacional, pero el Tribunal Supremo denegó su competencia y dio por zanjada la investigación.

16 Santaolalla López, F., Derecho Parlamentario español, Espasa, Madrid, 1990, p. 250.

17 Así lo entiende Obregón García, A., La responsabilidad criminal de los miembros del Gobierno: análisis del artículo 102 de la Constitución española, Cívitas, Madrid, 1996, p. 96. 
la seguridad del Estado en el ejercicio de sus funciones gubernamentales. Una vez aprobada la preceptiva iniciativa de acusación por la Cámara Baja, el ulterior proceso se desarrollará ante la Sala de lo Penal del Tribunal Supremo ${ }^{18}$.

Afortunadamente, no contamos con ejemplos de este tipo de responsabilidad, pues lo deseable es que sean situaciones harto extraordinarias, dado que estaríamos ante peligrosos intentos de conculcación del orden constitucional.

\section{B. La responsabilidad política a través de la «censura»}

La Constitución española de 29 de diciembre de 1978 asume, sin ambages, el sistema parlamentario (art. 1.3 CE), que reposa en la idea de que el parlamentarismo es una forma de gobierno esencialmente vertical precisamente por la relación de «confianza» que media entre Pueblo-Parlamento-Gobierno, en línea ascendente. Verticalidad que se puede extender también en el seno del propio Gabinete, pues el Parlamento puede otorgar su confianza únicamente al candidato que se le presenta en el momento de la investidura y este, a su vez, confía en los miembros que propone al Jefe del Estado como parte de su equipo de gobierno ${ }^{19}$. Por tanto, el Presidente del Gobierno necesita contar, en todo momento, con la confianza del Congreso de los Diputados (art. 99 CE) que, a su vez, debería comprobar la correcta y adecuada ejecución de la legislación. Esta comprobación que se realiza a través de instrumentos ordinarios y extraordinarios. Los primeros se materializan en las sesiones semanales de control del gobierno tanto en el Congreso de los Diputados como en el Senado a través de las denominadas preguntas, interpelaciones, mociones parlamentarias (art. 111, CE), etc. Los segundos hacen referencia a las fórmulas de exigencia de responsabilidad política que acontecen en circunstancias extraordinarias y, por lo general, con poca frecuencia a través de dos concretos institutos: la cuestión de confianza y la moción de censura.

Pasemos, pues, al comentario de las fórmulas constitucionales de exigencia de responsabilidad política que se recogen en los arts. 112 y $113 \mathrm{CE} / 78$ y se desarrollan en el Reglamento del Congreso de los Diputados, de 10 de febrero de 1982, Título VII, Capítulo II, arts. 173 y 174; los arts. 2 y 21, Ley 50/1997, de 27 de noviembre de organización, competencias y funcionamiento del Gobierno y los arts. 175 a 179 (Título VII, Capítulo III) del Reglamento del Congreso de los Diputados, de 10 de febrero de 1982 .

18 Un explicación más detallada de todo lo relativo a la responsabilidad penal en GonZÁLEz HERNÁNDEZ, La responsabilidad penal del Gobierno...op. cit.

19 Gonzalez Hernandez, E., «Veinticinco años de relación fiduciaria entre las Cortes Generales y el Gobierno», Revista de Derecho Político de la UNED, núms. 58/59, 2003, p. 530. 
a. Una cuestión de confianza en el olvido

En la cuestión de confianza se pretende revalidar la confianza (valga la redundancia) otorgada inicialmente al Presidente en situaciones en que pudiera parecer que ha perdido el apoyo parlamentario. De la redacción del art. $112 \mathrm{CE}$ : «El Presidente del Gobierno, previa deliberación del Consejo de Ministros, puede plantear ante el Congreso de los Diputados la cuestión de confianza sobre su programa o sobre una declaración de política general...» ${ }^{20}$, podría deducirse que más que un instrumento de responsabilidad política, en realidad, es, tan solo, un instrumento de «revalidación» de una confianza inicialmente otorgada, motivada por el cambio de algunos aspectos relevantes del programa que presentó en la sesión de investidura o por la necesidad de tomar nuevas medidas por circunstancias sobrevenidas de suficiente magnitud como para suponer un giro sustancial en la política del Gobierno. Es más, nuestra Constitución rechaza la posibilidad de plantear una «cuestión de confianza» para la aprobación de textos legislativos y el trámite por el que el Presidente del Gobierno ${ }^{21}$ solicita que se le revalide la confianza se ajusta a las reglas del procedimiento de investidura $^{22}$. De ahí que parezca razonable pensarlo.

El presidente del Gobierno verá revalidada la confianza por el voto favorable de la mayoría simple; requisito que, si bien es congruente con el elemento decisivo del proceso de investidura, también demuestra como la Constitución española de 1978 opta por garantizar la estabilidad gubernamental, al rebajar al mínimo posible los requisitos para entender que se sigue manteniendo la confianza parlamentaria. Así, si en la cuestión de confianza se alcanza la mayoría simple, se habrá logrado lo que realmente importa: testimoniar que el Presidente conserva la confianza del Congreso, aunque esta se haya visto reducida como lógica consecuencia del desgaste que produce el ejercicio de la acción de gobierno. Por ello, parece posible afirmar que ha terminado por convertirse en un instrumento de refuerzo del Gobierno frente al Parlamento, que, en los tiempos actuales ocupa un lugar secundario o menor en la vida parlamentaria. Ya afirmaba Pedro González-Trevijano que le vislumbraba un futuro

20 Figuraba como art. 90 en el Anteproyecto de Constitución y que apenas tuvo modificación alguna en el iter constituyente, salvo la relativa a la mayoría requerida para entender revalidada dicha confianza que pasó de mayoría absoluta a mayoría simple en la discusión en el Senado.

${ }^{21}$ El art. 112 CE tan solo exige que haya una «deliberación previa del Consejo de Ministros» que, en ningún caso, es vinculante. Es decir, que el Presidente no está obligado a seguir este criterio si fuese diferente al suyo, pudiendo plantearla para una rectificación respecto del programa expuesto en la sesión de investidura, o como consecuencia de una declaración de política general que parece aludir a declaraciones de importancia política considerable. El art. 174.1 del Reglamento del Congreso de los Diputados, tan solo dice que la cuestión de confianza se deberá presentar por escrito motivado, acompañado de la preceptiva certificación del Consejo de Ministros y calificación de este escrito por la Mesa de la Cámara para la verificación del cumplimiento de los requisitos formales. Según, art. 21.4 de la Ley 50 /1997, del Gobierno, el presidente en funciones no podrá someterse a una cuestión de confianza.

${ }^{22}$ Art. 174.3, RCD que prevé exposición de la «cuestión» por el presidente del Gobierno e intervención de los portavoces de los grupos parlamentarios. 
de escasa utilización ${ }^{23}$, como así ha sido en estos cuarenta años con tan solo dos ocasiones.

La primera fue la planteada por Adolfo Suárez, y se debatió los días 16, 17 y 18 de septiembre de 1980. El motivo no era otro que el desgaste sufrido meses antes por la moción de censura promovida por la oposición socialista en un contexto de grave crisis económica con una elevada tasa de paro e inflación. De modo que Adolfo Suárez, recibió un pequeño soplo de aire que le permitió continuar algunos meses más. La segunda ocasión tuvo lugar en 1990, en que Felipe González presenta una cuestión de confianza que se debate 5 de abril para subsanar la atípica votación de investidura al comienzo de la IV Legislatura, en la que no participaron todos los diputados como consecuencia de unos recursos presentados contra los resultados electorales ${ }^{24}$, sin mayor trascendencia.

Como ya decíamos, su uso ha sido mínimo. Parece poco probable que un Presidente del Gobierno la utilice para reforzar una posición algo debilitada por mucho que se esté ante situaciones de fragmentación parlamentaria. Además, debe descartarse también en situaciones de acusado bipartidismo o de victoria electoral por una clara mayoría. Pero si el Ejecutivo se viese ante las cuerdas por un Congreso fragmentado, que le niega la aprobación de todo proyecto legislativo que presente, el presidente podría plantearse tanto la cuestión de confianza como la disolución anticipada. Por supuestos como este, lo habitual ha sido caracterizarla de «órdago» que da el Gobierno por su propia iniciativa» ${ }^{25}$ o una «amenaza de suicidio del Gobierno» ${ }^{26}$. Pero, en España ni siquiera en estos casos se ha optado por ella. Así Rodríguez-Zapatero en 2011 prefirió la disolución anticipada ante un escenario parlamentario similar al de la actual Legislatura, en donde tampoco se prevé su uso. Si se plantease, el Congreso solo tiene dos opciones: mantener al actual presidente o retirarle la confianza y, si optase por esta segunda opción pesaría sobre él la pesada carga de tener que elegir un nuevo presidente. Ya se sabe, que esta puede resultar una labor harto complicada, hasta el punto, incluso, de conducir a nueva convocatoria electoral. Parece poco probable que un presidente se arriesgue. Por tanto, en una cuestión de confianza no pesará tanto la hipotética exigencia de responsabilidad política por la retirada de confianza como el mensaje que subyace sottovoce: «o yo o algo peor». Peor será, desde luego, si el Congreso se ve abocado a disolverse dos meses después porque no sea capaz de investir un nuevo Presidente. En esta tesitura, poco se hablará de responsabilidades políticas y mucho de gobernabilidad.

23 González-Trevijano, P., La cuestión de confianza, MacGraw-Hill, Madrid, 1996, p. 109.

${ }^{4}$ Un comentario a esta cuestión de confianza en PÉrEZ-SERrano JAUREGUí, N., «Crónica parlamentaria», Revista de las Cortes Generales, núm. 29, 1990.

25 Alzaga Villaamil, Ó., «Artículo 112», en Comentario sistemático a la Constitución española de 1978, 2. ${ }^{\circ}$ ed., Marcial Pons, 2016, p. 520.

${ }^{26}$ Cit., De Esteban, J. y González-Trevijano, P. J., Curso de Derecho Constitucional español, t. III, Servicio de Publicaciones de la Facultad de Derecho, Universidad Complutense, Madrid, 1994, p. 605 . 
Por todo ello, parece más razonable concluir que es un instrumento en manos del Presidente que le asegura mantenerse en una situación de confianza parlamentaria inicial aunque, incluso, cambie su programa de gobierno, pero no un instituto por el que se sustancie ningún tipo de responsabilidad política. Tan solo puede suponer la retirada de la confianza porque el nuevo programa o declaración de política general no sea del gusto del Congreso, siempre que el Presidente decida preguntarle.

Incluso en una situación de mayor fragmentación parlamentaria que la actual es difícil identificar escenarios políticos en que sea previsible que se ponga en práctica. Tal vez si se pretendiese reagrupar una mayoría en riesgo de dividirse, por ejemplo en el caso de gobiernos de coalición, o si se quisiese escenificar ante la opinión pública el porqué de la dimisión de un presidente que ya no cuenta con el apoyo del Congreso, buscando efectismo electoral y un buen posicionamiento de partida en el caso de una probable convocatoria electoral si el Congreso de los diputados no lograse investir un nuevo Presidente en el plazo de dos meses.

Resulta difícil sostener que se trata de un instrumento primigenio de exigencia de responsabilidad política. El nombre de las cosas no suele ser casual. Si se llama «cuestión de confianza» es porque es eso: una ocasión en la que se pregunta nuevamente al Congreso si revalida la confianza a un presidente que va a cambiar su programa. Así lo demuestra también su uso en Alemania, que, en 1982, en la única ocasión que ha triunfado una moción de censura, el canciller Helmut Kohl, nombrado a raíz de esta creyó no contar con una legitimidad indiscutida y decidió plantear la cuestión de confianza ${ }^{27}$. Que en el debate, la oposición critique sus medidas, le censure, repruebe o manifieste su parecer contrario a su política no lo convierte en un instrumento primigenio de exigencia de responsabilidad política, porque eso es lo habitual en la vida parlamentaria y ocurre cada semana en las sesiones de control al Gobierno. Cierto es que hay juicio negativo pero, en teoría, este no debería versar sobre la situación pasada sino sobre la nueva declaración o programa que se somete al juicio del Congreso de los Diputados. Por tanto, lo que el Congreso manifiesta es simplemente que no confía en ese nuevo programa de gobierno y, por tanto, decide iniciar la búsqueda de un candidato mejor. El art. 112 CE es una extensión de la letra del art. 99 CE que contempla el caso de que el programa inicial varíe y el Presidente entienda necesaria confirmar la confianza que se le dio en base a otras circunstancias. De ello es muestra el art. 114.1 CE: «1. Si el Congreso niega su confianza al Gobierno, este presentará su dimisión al Rey, procediéndose a continuación a la designación de Presidente del Gobierno, según lo dispuesto en el artículo 99. 2». No habla de censura al Presidente, ni de reprobación de su política, sino de no otorgarle la confianza, en la misma línea que el art. 99 CE.

27 Simón YarZa, F., «La moción de censura: ¿Constructiva u «obstructiva»?, Revista Española de Derecho Constitucional, núm. 103 (enero-abril), 2015, p. 96. 
b. La moción de censura: tres veces y ninguna dimisión

La moción de censura, sin embargo, si es un mecanismo constitucional que materializa, strictu sensu, una «censura» (valga la redundancia) al Gobierno. De ahí, que, sin duda alguna, deba ser considerado un instrumento destinado, en principio, a exigirle responsabilidades políticas por la que se considera una defectuosa gestión. En la moción de censura, como su propio nombre indica, el Congreso expresa públicamente una preferencia diferente, lo que, a la postre, supone un juicio negativo sobre la anterior. Aquí hay crítica, hay reprobación, hay juicio, hay, en una palabra, un vituperio, que derivará en la obligación de dimitir por parte del Presidente del Gobierno.

Sin embargo, este esquema se enreda por el carácter constructivo de la censura en la Constitución de 1978. Así, el art. 113 CE regula en un solo acto dos procedimientos constitucionales diferentes: el cese y la investidura de un nuevo Presidente, aunque uno de ellos necesariamente quedará difuminado o subsumido en el otro. Ya lo decía Aragón Reyes en 1986: «Ahí reside uno de los graves defectos de la regulación actual de nuestra moción de censura que aparece como figura estelar en el centro del debate no tanto el Presidente del Gobierno censurado como el candidato a Presidente que se propone. Se hace más hincapié en el debate sobre el Programa que este presenta que en la crítica a la labor del Gobierno que se censura. Aunque, en principio, ello puede parecer que potencia a la oposición, en realidad, no es así, porque prima más la «investidura» (que es lo improbable) que la «censura» (que es lo posible), es decir, que es lo que puede hacerse, aunque no se note la derrota del Gobierno ${ }^{28}$. De ahí que en la regulación parlamentaria de la censura, no se reserve protagonismo alguno a la figura del Presidente saliente que se desvanece hasta casi desaparecer. El foco en teoría deberá iluminar, tan solo, al nuevo candidato; lógica consecuencia de que la moción de censura sea también una investidura de un nuevo Presidente del Gobierno. Así, tal y como apunta el art. 114.2 CE: «Si el Congreso adopta una moción de censura, el Gobierno presentará su dimisión al Rey y el candidato incluido en aquélla se entenderá investido de la confianza de la Cámara a los efectos previstos en el artículo 99. El Rey le nombrará Presidente del Gobierno». Es decir, como el Congreso ya ha efectuado una votación, se entiende que ya ha puesto en marcha el procedimiento de elección e investidura de nuevo Presidente y, tan solo, procede la dimisión del Presidente saliente.

El sistema de censura que acoge la Constitución de 1978 encuentra su referente en la censura racionalizada y constructiva del art. 67 de la Ley Fundamental de Bonn de 1949, que impone importantes limitaciones al Congreso para que pueda exigir esta responsabilidad política al Gobierno. En definitiva, la censura en la Constitución

28 Aragón Reyes, M., «El control parlamentario como control político», Revista de Derecho Politico, núm. 23, 1986, p. 32. También Montero, J. R., «La moción de censura en la Constitución de 1978: supuestos constituyente y consecuencias políticas», Revista de Estudios Políticos, núm. 12, 1979, p. 16. 
española de 1978 no es tan solo una censura, sino que es una censura constructiva y como ya decíamos si «el lenguaje político no es inocente (tampoco frecuentemente el jurídico) resulta evidente que el término «constructivo» quiere significar buena y positiva, además de ser moderna y consiguientemente la censura clásica queda estigmatizada como destructiva, negativa y propia de los sistemas políticos atrasados» ${ }^{29}$. Así decía Alzaga: «no pretendo, por supuesto, extenderme sobre el tema de la inestabilidad de los gobiernos que es complejo y está en función del sistema de partidos y del sistema de representación proporcional, pero hay unanimidad de que esta también está en función de la forma de exigencia de responsabilidad política. En consecuencia, nosotros entendemos que el mecanismo que se establece (...) supone un progreso técnico importante porque básicamente logra eliminar el peligro de funcionamiento de mayorías negativas, que, sin embargo, no son positivas» ${ }^{30}$. Esta fue la postura que se defendió y repitió en los debates constituyentes, a pesar de que en Alemania tan solo se había producido un ejemplo que no llegó a buen puerto en 1972, con veintinueve años de vigencia en $1978^{31}$.

En un sistema como este, la destitución del Gobierno por el Congreso de los Diputados se vuelve extremadamente difícil, en aras de la estabilidad del Ejecutivo, pues está llamada a evitar las conocidas como «mayorías negativas» que sí tienen acuerdo para derribar a un Gobierno pero no lo tienen, en cambio, para la elección del sucesor. Esta fue la razón que, casi como un mantra, se repitió incansablemente durante los debates constituyentes, junto con ser garantía frente a la estabilidad gubernamental. De aquí todos los requisitos que se exigen tanto por el art. $113 \mathrm{CE}$ como por el 175.2 del Reglamento del Congreso según el que debe presentarse mediante escrito motivado y firmado por, al menos, una décima parte de los diputados, es decir, treinta y cinco, en que debe figurar también el nombre del candidato a ocupar la Presidencia del Gobierno, no poder ser votada hasta que transcurran cinco días desde su presentación y permitir la posibilidad de formular mociones alternativas $^{32}$. Estos nuevos requisitos pretenden seguir protegiendo al Gobierno ya constitui-

29 Torres del Moral, A., «Responsabilidad política de los ministros», Diario del Derecho. Iustel, (URL: http://www.iustel.com/diario_del_derecho/noticia.asp?ref_iustel=1166274, fecha de consulta: 13 de septiembre de 2107).

30 Alzaga Villamil, Ó., «Artículo 113», en Comentario sistemático a la Constitución española de

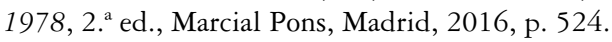

31 Solo se ha aplicado una vez con éxito en 1982 con ocasión de la censura del social-demócrata Helmut Schmidt por Helmut Kohl del CDU-CSU.

32 En esta línea de consideraciones los cinco días parecen referidos a días hábiles, si aplicamos el art. 90.1 del Reglamento del Congreso, que establece como norma general que los plazos se computen por días hábiles. Según art. 176.2 del Reglamento del Congreso (en adelante RC), las mociones alternativas deben cumplir los mismos requisitos que la inicial, por tanto, su presentación por, al menos, una décima parte de los diputados, en escrito motivado y con un candidato alternativo a la Presidencia que haya aceptado como tal. Su debate seguirá lo establecido en el art. 177. $1 \mathrm{RC}$ con un primer turno de explicación de los proponentes de la moción por uno de los diputados firmantes de la misma, sin limitación de tiempo, seguido de la intervención del candidato propuesto, también sin limitación de tiempo, a efectos de exponer el programa político del Gobierno que se pretende formar. Después tendría 
do que tendría tiempo para intentar revertir una situación que se le manifiesta desfavorable, si bien el debate se centrará en la discusión del programa del candidato, intentando balancear la situación de los dos poderes que se oponen. He aquí donde se centra el grueso de las críticas sobre la «censura» en España de sobra conocidas, hasta el punto de que paradójicamente su carácter «constructivo», que parecía ser el adalid de la estabilidad de nuestro sistema, ha sido calificado y considerado como todo lo contrario: «una institución que rompe con el principio clásico del parlamentarismo, a saber, que el Gobierno ba de contar con la confianza parlamentaria» ${ }^{33}$.

Además, según aptdo. 4 del art. 113 CE, en caso de ser rechazada una moción de censura, sus signatarios no podrán presentar otra durante el mismo período de sesiones, para evitar la repetición injustificada de estas mociones, habida cuenta de su trascendencia política ${ }^{34}$. Un requisito más que redunda en la demostración de las escasísimas posibilidades de éxito de una moción de censura que se traduce en el mantenimiento del Gobierno hasta el final de la Legislatura en el caso de Gobiernos que cuenten con una sólida mayoría absoluta y, al máximo, hasta una disolución en el caso que no cuenten con tan sólida mayoría. En el primer supuesto, el triunfo de una moción de censura pasa por una división en los bancos de esa mayoría, posibilidad que la práctica se revela como harto improbable, habida cuenta de la disciplina interna de los partidos. Como también parece poco probable que haya un abandono de varios diputados de esa formación política. Otra cosa, sería que la mayoría absoluta fuese tan justa que bastase con uno o dos, si bien sigue siendo improbable. Si se tratase de un Gobierno de coalición o investido por mayoría simple las posibilidades suben para que se fragüe una mayoría alternativa, pero no tanto como para salvar el requisito del candidato alternativo.

Desde la letra de la Constitución, el Gobierno puede ser depuesto y sustituido por el Congreso de los Diputados si se le presentase una moción de censura y está obtuviese la mayoría absoluta de los votos pero, en la realidad política, nunca se ha manifestado de tal modo. Estos últimos cuarenta años que se han caracterizado por un uso y «disfrute» desigual de la responsabilidad política en España, pues como certeramente recuerda González-Trevijano «la exigencia de responsabilidad política

\footnotetext{
lugar el turno de portavoces de los grupos parlamentarios, por tiempo de treinta minutos cada uno, pudiendo consumirse además turnos de réplica de diez minutos (art. 177.2 RC). En el caso de que se hubieren presentado mociones alternativas, según art. 177.3 RC, el Presidente de la Cámara, oída la Junta de Portavoces, podrá acordar el debate conjunto de todas ellas. La votación se realiza en su modalidad de pública mediante llamamiento nominal (art. 85.2 RC). En caso de haberse presentado mociones alternativas, la votación de estas deberá producirse separadamente y siguiendo el orden de su presentación. Si se aprobase una de estas mociones no se someterán a votación las restantes (art.177.6 RC). Las abstenciones, los votos nulos o los votos en blanco y las ausencias juegan en contra de su aprobación, porque jurídicamente significan lo mismo que el voto en contra.

33 SimÓN YARZA, op. cit., p. 89.

${ }^{34} \mathrm{El}$ artículo $179 \mathrm{RC}$ añade que la moción de censura presentada en período entre sesiones se imputará al siguiente período de sesiones.
} 
ha sufrido importantes cambios desde los tiempos del parlamentarismo clásico, de manera que esta ya no se limita, prima facie, a la remoción del Gobierno ${ }^{35}$.

En un principio, quizás por la novedad que suponía estrenar un Texto constitucional, por la situación de mayor fragmentación parlamentaria o por la propia inestabilidad de un sistema constitucional recién estrenado hubo cierto auge de uso de la censura que, si bien, nunca llevó aparejada la dimisión, sí tuvo algún efecto y resultó, en cierta manera, eficaz, al menos, en su vertiente de responsabilidad política difusa. Así se demostró con ocasión de la primera moción de censura tan solo un año y medio después de la promulgación de la Constitución de 1978, concretamente en mayo 1981 contra Adolfo Suárez, llevando como candidato a Felipe González ${ }^{36}$. El contexto era el de desarticulación de la mayoría parlamentaria de UCD que se «desangraba», parlamentariamente hablando. Por ello, se veía con buenos ojos la utilización de esta fórmula por la oposición socialista «como el arma político-parlamentaria más importante para concentrar el interés de la opinión pública en la supuesta ineficacia del Gobierno y en la pretendida bondad de un programa político alternativo, en la línea de ruptura con la política de consenso de la etapa constituyente e intento de propiciar una nueva mayoría electoral favorable al proyecto socialista» ${ }^{37}$. Si bien, no obtuvo los votos necesarios no puede ser menospreciada porque su retransmisión televisiva en un momento en que el grueso de la información política se trasladaba o por la prensa escrita o por la TVE supusieron, sin duda alguna, el «reforzamiento» de la posición de Felipe González en términos de visibilidad y presencia en el espacio político que contemplaba el español medio. Alcanzó un indiscutido éxito político y de imagen con vistas a la siguiente convocatoria electoral, como así resultó $\operatorname{ser}^{38}$. En definitiva, «el PSOE consiguió su objetivo de hacer conferir credibilidad a su programa y de colocar en una excelente situación política a su líder» ${ }^{39}$.

Por estas razones, se ha defendido que, en España, la censura parlamentaria buscaba, no tanto remover al Gobierno, como desgastarlo. En definitiva, utilizar la censura como un instrumento si bien de honda resonancia, en el debate político que situaba al «fallido» candidato en una buena posición en la próxima consulta electoral. Pero, la siguiente ocasión en que tuvo lugar una moción de censura, viene a demostrar lo contrario, hasta el punto de iniciar una nueva etapa de abandono de este tipo de institutos. Nos estamos refiriendo a la censura de 23 de marzo de 1987 contra Felipe González, en que el senador Antonio Hernández Mancha de AP, figuraba como candidato alternativo ${ }^{40}$. En este caso, también la lógica matemática jugaba en contra de

35 GonZÁlez-Trevijano,op. cit., p. 108.

36 Diario de Sesiones del Congreso de los Diputados, de 28, 29 y 30 de mayo de 1980.

37 Virgala Foruria, E., La moción de censura en la Constitución española de 1978, Centro de Estudios Constitucionales, Madrid, 1988, p. 271.

38 Torres Del Moral, op. cit.

39 Virgala Foruria, op. cit., p. 280.

40 Diario de Sesiones del Congreso de los Diputados, núm. 56, de 26, 27 y 30 de marzo de 1987. El texto de los firmantes de la moción también en: Revista de Derecho Político, núm. 26, 1988, pp. 188 a 186 
los signatarios, pero volvieron a ser consideraciones políticas las que empujaron a su presentación, entre otras que Hernández-Mancha era senador por lo que necesitaba de visibilidad en la Cámara de representación popular y la necesidad electoral de demostrar los errores de gestión del gobierno socialista. Fracasó en todos los sentidos, tanto numérica como políticamente, porque no supo obtener rentabilidad electoral.

Tras este fracaso, se inicia una nueva etapa en que «se tiene la sensación de que los hechos van por un lado y las responsabilidades por otro» ${ }^{41}$. Es una larga etapa en la que la vida parlamentaria abandona la responsabilidad política en mayúsculas que supone el debate y votación de una censura hasta 2017, con, tan solo, algunos episodios de mociones de reprobación de algunos ministros y poco más.

La cuestión es si con la última moción de censura, que se debatió en el Congreso de los Diputados los días 13 y 14 de junio de $2017^{42}$ en que Pablo Iglesias se postulaba como candidato a la Presidencia de Mariano Rajoy, se ha iniciado una nueva etapa o si, por el contrario, está en la línea de las dos anteriores buscando solo rédito electoral o desgaste del Ejecutivo. Un primer y apresurado análisis llegaría a la conclusión de que obedecía a esa estrategia electoral de desgaste del Gobierno, pues coincidió con la planteada a Cristina Cifuentes por el grupo de Podemos en la Asamblea de Madrid, con tan solo 27 escaños y que se debatió el 8 de junio de 2017. Sin embargo, es posible considerar otros motivos. A saber: dar conocer a su candidato (si bien de sobra conocido) o reforzar o intentar relanzar la figura del líder con menor presencia en los medios y menoscabada en su pretendida, pero no conseguida, posición parlamentaria de partido de la oposición para forzar el famoso sorpasso. $\mathrm{O}$, como dice García Fernández, restar protagonismo al PSOE en sus primarias que le impidiese también presentar una moción alternativa: «el único día del año 2017 en que el PSOE no puede utilizar una facultad constitucional ha sido el escogido por Podemos», sentencia ${ }^{43}$.

La cuestión está en dilucidar si una censura que solo logró contar con el apoyo de ERC, Bildu y Compromis ${ }^{44}$ en un Congreso tan fragmentado refleja ese teórico desgaste del Gobierno. Ni siquiera contó con el voto afirmativo del PDeCat, a pesar de la brecha que suponían sus aspiraciones independentistas. $\mathrm{O}$ si, por el contrario lejos de fortalecer la exigencia de responsabilidades políticas al Gobierno, en realidad, la minusvaloran aún más ${ }^{45}$. Es decir, que habría tenido la lamentable consecuencia de

(URL: http://e-spacio.uned.es/fez/eserv.php?pid=bibliuned:Derechopolitico-1988-26-2331B726\&dsI$\mathrm{D}=\mathrm{PDF}$, fecha de consulta: 13 de septiembre de 2017).

${ }^{41}$ Diario de Sesiones del Congreso de los Diputados, núm. 28, de 5 de abril de 1990, pp. 1058 y 1059.

${ }^{42}$ Fue presentada el 26 de mayo, según consta en el Diario de Sesiones del Congreso de los Diputados, núm. 161, de 26 de mayo de 2017, pp. 2.

43 García Fernandez, J., «Moción de censura», El País, 20 de mayo de 2017.

${ }_{44}$ PSOE, PNV y PDeCat se abstuvieron. En contra PP, CDs y CC.

45 De opinión muy similar García Fernandez, J., «La moción de censura en España: funcionalidad y ¿reforma?», Cuadernos para el debate, núm. 273-274 (agosto-septiembre), 2017, p. 42, que sostiene como la censura se ha convertido en un instrumento de control-información, en lugar de control-sanción. 
rebajarla a mero instituto de control, un instrumento más en la refriega, que, ni siquiera es capaz de manifestarse a través de una responsabilidad política difusa. Recuerda Virgala Foruria, que el éxito o el fracaso de una moción de censura constructiva dependerá de muchos factores o condiciones como pueden ser el escoger el momento oportuno, la existencia de un gobierno dividido, la propuesta de una alternativa de gobierno creíble, aunque no llegue a triunfar en ese concreto momento, y un buen candidato a la Presidencia del Gobierno que sepa comunicar a la opinión pública la necesidad de un cambio gubernamental en el futuro etc. pues de lo contrario puede tener un efecto boomerang y reforzar al Gobierno, al permitirle demostrar ante el electorado la irrelevancia de la oposición como alternativa ${ }^{46}$. En el contexto de 2017, no me atrevería a afirmar lo segundo pero sí la primera parte, pues ni el momento pareció el más oportuno, ni peligraban el apoyo de Ciudadanos al gobierno de Mariano Rajoy, ni se situó en el agenda política soluciones concretas y eficaces a los problemas del país, ni el candidato tenía posibilidades de presentarse como una opción solvente y sólida, pues ni siquiera negoció apoyos antes de su presentación. Poco se puede esperar, salvo la nada, una «nada» cubierta de una incómoda incertidumbre. Como diría un labriego: para este viaje no necesitábamos tales alforjas. Se la llegó a calificar en la prensa del día siguiente de «frivolidad extemporánea y vanidosa» ${ }^{47}$, de «cariz poco halagüeño» ${ }^{48}$, incluso de «apariencia fraudulenta porque sus fines se separan de los que fija la Constitución: posterga la democracia representativa, no se ha negociado con los partidos que la harían triunfar y se ha presentado en una fecha que imposibilita la presentación de una moción alternativa por parte del PSOE» ${ }^{49}$. Es más, se bromeó en las filas del Gobierno con ser más una «moción de impostura» que de verdadera «censura».

Lo cierto es que la figura de Pablo Iglesias se encontraba por aquellas fechas en horas bajas. Así según el Barometro del CIS, Estudio n. ${ }^{\circ} 3173$, de abril de 2017 50 , la valoración ciudadana de Pablo Iglesias si situaba en un bajo 2,91, por debajo del resto de líderes políticos, incluso de Mariano Rajoy que obtenía un 2,99. De ahí que una de sus claves pudiese estar en el intento de mejorar la percepción ciudadana de Pablo Iglesias como próximo presidente. La cuestión es si lo consiguió. No parece, pues según el Estudio n. ${ }^{\circ} 3183$, del CIS: Barómetro de julio de 2017, Pablo Iglesias apenas había subido a un 2,95, lo que, a priori, no parece una desviación significativa. Mientras que Mariano Rajoy prácticamente se mantenía con un 2,98 ${ }^{51}$. El discurso de candidato a la Presidencia no pareció convencer a los españoles.

\footnotetext{
${ }^{46}$ Virgala Foruria,op. cit, p. 287.

${ }^{47}$ El País, 14 de junio de 2017.

48 Torres del Moral, A., «Censurar ¿para qué?», El Mundo, 13 de junio de 2017.

${ }^{49}$ García Fernandez, «Moción de censura»...op. cit.

${ }^{50} \mathrm{http} / / /$ www.cis.es/cis/export/sites/default/_Archivos/Marginales/3160_3179/3173/es3173mar. pdf

${ }^{51}$ http://www.cis.es/cis/export/sites/default/-Archivos/Marginales/3160_3179/3173/es3173mar. pdf
} 
Otro motivo es el del rédito electoral, pero, de ser este el motivo principal, extraña que se presente apenas seis meses después de comenzada la Legislatura. A juzgar de las declaraciones posteriores de líderes de Unidos Podemos en que se apuntaba la posibilidad de una nueva censura en el siguiente período de sesiones, parece ser que obedecía más al puro desgaste, junto con el intento de mostrar al líder de Unidos Podemos como líder de la oposición, a pesar de ser la tercera fuerza política. Si bien una nueva censura no tiene visos de concretarse pues la agenda política se ha visto arrollada por la «vicenda catalana».

En definitiva, esta tercera moción pareció no servir para nada. Bueno, siendo justos, sí ha servido para algo: para que comenzase a cundir la idea de que la moción de censura ya no es lo que era, es decir, que ya ni siquiera sirve para desgastar al Gobierno. Y es que, hasta la fecha, se reconocía a la moción de censura constructiva otra función al margen de la de derribar al Gobierno: una función latente, que podía ser utilizada para formar una confrontación entre el presidente del Gobierno y el candidato propuesto, que, en ciertos casos, sería inviable de otra manera ${ }^{52}$. Pues, hasta esto parece haberse desvanecido.

\section{EL FUTURO QUE ESTÁ POR LLEGAR}

La experiencia demuestra que en ningún caso ha conducido a derribar al Gobierno ni a sustituirlo y tampoco parece que determine, de un modo indubitado, cierta responsabilidad política difusa. Probablemente ello obedezca a la ya aludida circunstancia de que nuestro modelo de partidos (y en parte nuestro sistema electoral) ha contribuido durante mucho tiempo a la estabilidad de los gobiernos, en la medida en la que estos estuvieran respaldados por mayorías absolutas o amplias que dificultaban el que toda la oposición pudiera ponerse de acuerdo sobre un candidato alternativo» ${ }^{53}$. Por tanto, ya no se trataría solo de una regulación constitucional de la censura constructiva, sino que parece derivarse de otros defectos endémicos de un sistema constitucional, sin duda mejorable, desde estrictas consideraciones de calidad democrática. Así, afirma García Fernández que «esa función inhibitoria de la censura tiene como consecuencia que en España apenas tenga vigencia el principio constitucional propio del parlamentarismo, que otorga al Parlamento la posibilidad de deshacer la relación fiduciaria que se anuda con el Gobierno a través de la moción de censura» ${ }^{54}$. Además, de romper el difícil equilibrio Gobierno-Parlamento en favor del primero y de evidenciar, otra vez que los Parlamentos, al menos, en España, no terminan de encontrar su sitio. Parecen haber

52 Simón YARZA, op. cit., p. 98.

53 Díaz Revorio, F. J., «La función de control y responsabilidad política», en «La reforma de la Constitución», dir. E. Álvarez Conde (dir.) Reflexiones y propuestas sobre la reforma de la Constitución española, Comares, Granada, 2017, p. 273.

${ }^{54}$ García FernandeZ, «La moción de censura en España: funcionalidad...op. cit., p. 41. 
pasado de la omnipotencia (si alguna vez la tuvo) al desconcierto por el que, a veces actúa, o así lo parece, como un coro de peregrinos, cumpliendo penitencia por errores pasados y otras persigue protagonismo casi siempre fugaz ${ }^{55}$.

Como decía Adolfo Posada en su Estudio sobre régimen parlamentario en España: «los Parlamentos españoles, tienen un pecado de origen verdaderamente imborrable. No hay Jordán que los purifique». Ahora bien, debemos ser justos. Este mal endémico no es solo un «mal español». En el fondo, este modelo parlamentario de exigencia de responsabilidad siempre ha estado en tela de juicio. Ya en 1843 afirmaba Welcker que «ni la responsabilidad meramente parlamentaria de las deliberaciones públicas en las Asambleas estamentales ni la no aprobación de los impuestos ni las declaraciones de indignidad son suficientes, pues poseen, en parte un tono de guerra partidistas y, realmente, solo logran una fuerza y estima adecuada cuando detrás de ellas existe una responsabilidad penal [...] hacen falta unas instituciones mucho mejores que las nuestras. Las mociones de censura contra los ministros dependen de la aprobación de las primeras Cámaras y que (...) no realizan verdaderamente la responsabilidad ministerial» ${ }^{56}$.

Por tanto, el Derecho constitucional parece estar abocado a la ley del péndulo: o admite sistemas de censura laxos u opta por garantizar la gobernabilidad, la estabilidad de los Consejos de Ministros y el fortalecimiento institucional, aunque sea consecuencia de una artificial impostura. Es como si el beneficio logrado por una institución equivaliese automáticamente a una pérdida de lo otro ${ }^{57}$.

Es verdad que la valencia de una censura no tiene que venir tan solo de su aprobación, es decir, el éxito no tiene por qué estar tan solo en la remoción por los votos de la mayoría absoluta del presidente, pues «su virtualidad va más allá del simple recuento de votos: una censura fallida o una confianza ganada puede ser un éxito o un fracaso, según la percepción arbitraria de la psicología colectiva» ${ }^{58}$. El control de la Asamblea tiene una utilidad negativa no calculable, pues, gracias a él muchas cosas no se harán o se harán algunas que si no, se habrían omitido ${ }^{59}$. A pesar de esto, parecen necesarios ciertos cambios que adapten estas figuras algo desfasadas a las demandas de una ciudadanía más crítica y que exige la realización efectiva de la máxima que obliga al Gobierno a responder ante sus representantes en el Parlamento.

55 Pendas García, B., «Regeneración democrática. Reflexiones y propuestas», en En pro de la regeneración política de España, dirs. E. Arnaldo Alcubilla y P. González-Trevijano, Fundación URJC/ Fundación Canal Isabel II, Madrid, 2015, p. 50.

56 Welcker, C. T., «Responsabilidad de los príncipes y los ministros», en Liberalismo alemán en el siglo XIX. 1815-1848, Rotterck, Welcker, Pfizer y Mohl, Centro de Estudios Constitucionales, Madrid, 1987, pp. 89 y 91.

57 Montero, op. cit., p. 23.

58 Pendas García, op. cit., p. 51.

59 Von MoHL, R., «Sobre la responsabilidad de los ministros en las Monarquías constitucionales», en Liberalismo alemán en el siglo XIX. 1815-1848, Rotterck, Welcker, Pfizer y Mohl, Centro de Estudios Constitucionales, Madrid, 1987, p. 160. 
Cada nuevo escándalo de corrupción pone en el punto de mira las normas constitucionales sobre la responsabilidad gubernamental ya sean penales o políticas, introduciendo en el discurso público referencias constantes al «buen gobierno», a «la rendición de cuentas», a «la transparencia en la acción de gobierno», al «comportamiento ético» etc., con tal fuerza, magnetismo y carga emocional que han terminado por enredar aún más una cuestión ya sobradamente compleja.

El problema, por tanto, sigue siendo el mismo: cómo hacerla efectiva, es decir, cómo materializar ese control (o accountability ${ }^{60}$ ) del Gobierno. No basta con afirmaciones de carácter general, porque, a la postre, siempre será necesario disponer de herramientas y de mecanismos constitucionales que hagan efectivas las afirmaciones o principios jurídicos generales. Las fórmulas constitucionales de exigencia de responsabilidad política se tornan en el elemento indispensable si se quiere garantizar un alto nivel de calidad democrática capaz de mantener intacto el lazo de confianza entre la ciudadanía y sus representantes.

Por mucho que se insista en que «la luz del sol es el mejor desinfectante», según las palabras del juez estadounidense Louis Brandeis ${ }^{61}$, sigue siendo necesaria la presencia de un andamio legal (y constitucional - EGH-) con capacidad para imponer la ley y para hacer que los gobernantes actúen de acuerdo con ello ${ }^{62}$. Pero las Constituciones actuales (y la española no es una excepción) no terminan de diseñar un eficaz procedimiento de rendición de cuentas. El reto sigue siendo el mismo: frenar, limitar ese halo de irresponsabilidad e impunidad que acompaña al poder y que le empuja irremediablemente a olvidar ciertos márgenes éticos y/o legales. Ya lo decía Carl Theodor Welcker: «No existe derecho donde faltan medios para realizarlo con la fuerza necesaria» ${ }^{63}$.

Una de las claves estaría, pues, en desincentivar la ventaja que supondrían las conductas corruptas, lo que nos conduce nuevamente al mismo punto, si bien, por otro camino: el de los atolones de cierta irresponsabilidad que pueden seguir presentes en normas constitucionales y/o legales y que impiden garantizar una verdadera rendición de cuentas. La calidad de la democracia requiere de un importante grado de confianza de los ciudadanos en sus instituciones, lógica consecuencia de una opinión pública crítica y vigilantes y con elevadas exigencia éticas. Y es que

${ }^{60}$ Etimológicamente el término proviene del siglo xI, en el reinado de Guillermo I en donde significaba bookkeeping o «custodia del libro», es decir, del libro que contenía el censo de propietarios de su reino a los que acudía en caso de necesidades económicas de mantenimiento del estado y que, en consecuencia, rendían cuentas de sus posesiones frente al Monarca en los conocidos como DomesdayBooks y al que juraban, a su vez, lealtad. No será hasta el siglo xx hasta que el término evolucione tanto, que, en realidad, es una auténtica vuelta a la tortilla, porque ahora serán los responsable públicos los que deban rendir cuentas

61 Pendas García, op. cit., p. 44.

62 Wences Simon, I., «Cultura de la legalidad y rendición de cuentas social», en Cultura de la legalidad. Instituciones, procesos y estructuras, eds. M. Villoria Mendieta e I. Wences Simón, Catarata ed., Madrid, 2010, p. 76.

63 WelCKER,op. cit., p. 87. 
«la corrupción política repugna la conciencia cívica. Tiene un efecto demoledor sobre la legitimidad del sistema y produce efectos negativos en cadena (...) Puede calificarse, por ello, de cáncer de la democracia» ${ }^{64}$. Este es el contexto sobre el que se asienta la visión panorámica de la responsabilidad gubernamental, situación que no deja de ser peligrosa, porque la crisis económica ha reforzado la idea de que los políticos tienen que ser ejemplares.

A la postre, todo debate termina en medir la calidad de nuestra democracia y las posibilidades de renovación de aquellos mecanismos jurídico-constitucionales que no funcionen. Se tendrá que medir si nuestra democracia es de baja calidad y si lo es, qué elementos ayudarían a mejorarla. Entre todos los posibles, hay uno que, sin duda, se repite: los sistemas de control y rendición de cuentas, la responsabilidad que se debe asumir y la respuesta a que se está obligado. Ahora bien, «las reglas deben ser claras y precisas, eliminando las dudas que genere la opacidad» ${ }^{65}$, para lo que el Congreso necesitará adaptar, reformar y reformular las vías y medios para que el Gobierno sea más transparente y, por ende, responsable. Si en los actuales sistemas los órganos de control horizontal se encuentran dominados por el Gobierno se impone, pues, la necesidad de reinventarse. Si la responsabilidad individual del presidente del Gobierno, es irrealizable, tal vez se haya errado en el objetivo. Tal vez haya que intentar derribar al Gobierno, dejándole sin armeros. Es decir, no se trata de intentar que el presidente dimita para que caigan los ministros, sino que este dimita a aquellos colaboradores que, a juicio de la Cámara, están errando gravemente en su gestión. Derribar a los peones para arrinconar al Rey. Con esto, el Congreso se sigue garantizando ese papel protagonista y prevalente que debería tener.

No hay otra solución adaptarse para pervivir. Se impone la modulación de unas fórmulas demasiado rígidas y, en cierto modo, anacrónicas. Tal vez baste con un formato más ágil, pues coincide García Escudero en que es posible constatar la inadecuación de los actuales instrumentos de control para la finalidad que pretenden, esto es, verificar si la actuación del Gobierno se acomoda al criterio del Parlamento, pues de no ser así, si se precisa exigirle una respuesta, pues «en un sistema parlamentario como el nuestro en que la mayoría quiere lo que quiere el Gobierno, es ilusorio pensar que aquella controle o este se deje controlar ${ }^{66}$. De lo contrario, se corre el riesgo de que se desencadene una censura contra el Gobierno, que puede ser irracional, irreflexiva, desinformada y de aquellas que no ven más allá de su propio jardín, como decía Voltaire.

${ }^{64}$ Pendas García,op. cit., p. 43.

${ }^{65}$ Ibidem, pp. 44 y 45.

${ }^{66}$ García Escudero, P., «La regeneración del Parlamento. El papel del Congreso, el Senado y los Parlamentos autonómicos», en En pro de la regeneración política de España, dirs. E. Arnaldo Alcubilla y P. González-Trevijano, Fundación URJC/Fundación Canal Isabel II, Madrid, 2015, p. 456. 
Esto nos introduce en el comentario de una nueva etapa que, sin duda, tendrá que manifestarse más tarde o más temprano, si es que no ha empezado ya a dar «brotes verdes», que no es otra que la de la revitalización de una «responsabilidad política de mínimos», a través de la reconsideración y reformulación constitucional de las mociones individuales de reprobación y de otras fórmulas parlamentarias. Algunos apuestan por la instauración de los conocidos como recalls o referéndums o acciones revocatorias en los que un mínimo de ciudadanos puede solicitar la revocación de determinados cargos o responsables públicos; revocación que se materializará de alcanzar determinada mayoría en el referéndum que se celebre, pero esto, recuerda Díaz Revorio, «rompería por completo el esquema de la confianza y la responsabilidad propia del modelo parlamentario» ${ }^{67}$. Podría ser admisible para diputados y senadores que sí son elegidos directamente por el pueblo, pero ni estamos hablando de la responsabilidad de los miembros del Legislativo ni puede olvidarse que la experiencia de otros países que ha dado lugar a utilizaciones torticeras o abusivas. Lo que requiere, por tanto, de un sistema bien estructurado en los controles previos, a posteriori y de continuum para evitar abusos.

Sí caben en nuestro sistema parlamentario las mociones individuales de reprobación, gracias a la letra de los arts. 64.2, 111.2 y 98.2 CE. Así, a pesar de las iniciales reticencias sobre su constitucionalidad, hoy en día parece difícil seguir negando su utilidad. La experiencia política de otros países europeos (Suecia, Italia, Alemania...), y también la española se adscriben al reconocimiento, al menos de facto, de esta responsabilidad política individual de los ministros, si bien sui generis, porque no lleva aparejada la obligatoria dimisión del Ministro reprobado.

La primera vez en que se puso en marcha este mecanismo fue en septiembre de 1981 como consecuencia de la venta por vías ilegales de aceite de colza en mayo del mismo año. El 11 de abril de 1984, se admitió nuevamente a trámite una moción de reprobación presentada por el grupo Popular en el Congreso contra el ministro de Justicia Ledesma Bartet, basándose en que las reformas legislativas de éste eran las causantes del aumento de inseguridad ciudadana. Otros supuestos son los de 25 de octubre de 1984 y 23 de septiembre de 1987. En el primero, el grupo Popular propuso en el Congreso de los Diputados la reprobación de los ministros de Justicia, Presidencia, Administración Territorial y Asuntos Exteriores. En el segundo caso, la moción fue presentada contra el Ministro de Economía y Hacienda por el Grupo parlamentario Popular, dentro de una moción general sobre el balance de la adhesión de España a la Comunidad Europea. Otros ejemplos son las reprobaciones contra el entonces ministro Arias Salgado de 20 de abril y 10 de diciembre de 1999. Todas ellas fueron rechazadas. Pero en el segundo gobierno de José Luis Rodríguez Zapatero, investido solo por mayoría simple, en el Senado se aprobó la reprobación de la entonces ministra de Fomento, Magdalena Álvarez, que presentó el grupo parlamentario Popular. Una situación similar a las recientes reprobaciones de los

${ }^{67}$ Díaz Revorio, op. cit., p. 280. 
ministros Cristóbal Montoro ${ }^{68}$ y Rafael Catalá ${ }^{69}$. Si bien, la de 31 de octubre 2012 contra José Ignacio Wert, presentada por el grupo parlamentario Socialista fue rechazada. Pero ya se sabía, en esta ocasión el Ejecutivo de Rajoy contaba con mayoría absoluta.

No se puede dudar de su valor en contextos de fuerte fragmentación o polarización del Parlamento. Imagínese el caso de que un ministro/a sea reprobado dos veces. Difícil parece, pero difícil será también para el presidente del Gobierno mantenerle después de dos reprobaciones. Aunque no lo haga coincidir en el tiempo (eso es seguro), a la larga es probable que termine cesándolo.

Ciertamente la Constitución española no recoge la obligatoria dimisión del ministro reprobado, pero dado que la moción de censura no garantiza ese sacrosanto principio de responsabilidad ministerial pareciera conveniente que nuestro ordenamiento admitiese un procedimiento de exigencia de responsabilidad política de los miembros individuales del Gobierno a fin de hacer más efectivo el control del Parlamento, pues no se puede decir seriamente que el sistema de gobierno contenga todas las piezas necesarias para asegurar una integral responsabilidad política del Ejecutivo ${ }^{70}$. Como dice Montero, resulta sorprendente o, cuanto menos, significativo que nuestra Constitución, incluso en su art. 113 , olvidase la censura individualizada de un ministro ${ }^{71}$. Sobre todo porque la Constitución española de 1978, no tanto en la letra pero si en el fondo, asume un modelo de responsabilidad personalísimo, tanto en lo penal (como es lógico) como en lo político, porque tanto la cuestión de confianza como la moción de censura se centran en el papel desarrollado por el presidente del Gobierno.

Tal vez hayamos estado errando el tiro. Tal vez hayamos estado considerando mal el objetivo a batir, salvando las distancias del símil balístico. O, cuanto menos, hayamos orientado mal la «estrategia de responsabilidad». Así, en lugar de intentar la «respuesta» del presidente, haya que poner negro sobre blanco los errores de los ministros. En un contexto en el que el presidente del Gobierno necesita del apoyo de otras fuerzas políticas, además de su grupo parlamentario, quizá se vea obligado a cesarle antes de poner en riesgo tan imprescindibles apoyos.

68 Diario de Sesiones del Congreso de los Diputados, núm. 65, de 27 de junio de 2017: Moción consecuencia de interpelaciones urgentes: del grupo parlamentario socialista, sobre las responsabilidades políticas que piensa asumir el Ministro de Hacienda y Función pública como consecuencia de la sentencia del Tribunal Constitucional que declara inconstitucional y nula su amnistía fiscal (número de expediente 173/000036).

69 Diario de Sesiones del Congreso de los Diputados, núm. 53, de 16 de mayo de 2017: Moción consecuencia de interpelaciones urgentes: del grupo parlamentario socialista, sobre las responsabilidades políticas que piensa asumir el Ministro de Justicia como consecuencia de las maniobras que se han producido en el seno del Ministerio Fiscal dirigidas a obstaculizar determinadas causas judiciales contra la corrupción y de las propias actuaciones del ministro en relación con estas causas (número de expediente $173 / 000029)$.

70 Torres del Moral, «Responsabilidad política de los ministros»... op. cit.

71 Montero, op. cit., p. 13, a diferencia del art. 64 de la Constitución de 1931. 
Tal vez haya que pensar en soluciones algo más imaginativas para salir de la tesitura en la que nos encontramos: o estabilidad gubernamental o censura parlamentaria laxa que permita fácilmente la responsabilidad política. Durante casi cuarenta años se ha repetido como un mantra que en el artículo $113 \mathrm{CE}$ se confunden estabilidad política y estabilidad gubernamental. Sin embargo, puede haber algo de verdad y la censura constructiva sí garantice algo de estabilidad política en ciertos momentos. En 1978/79 buena parte de la estabilidad política pasaba porque se asentase una Constitución recién aprobada. De ahí que como señaló Alzaga ${ }^{72}$, y recuerda García Fernández, el acuerdo entre el PSOE y UCD fue fácil ante el temor de que una moción de censura atrajera votos de la extrema derecha y la extrema izquierda de entonces $(\mathrm{AP} \text { y PCE })^{73}$. Eran necesarios gobiernos que permitiesen que la Constitución de 1978 echase a andar. Pensemos ahora en el contexto de 2016/17 de inusual fraccionamiento del arco parlamentario, con serias dificultades para elegir presidente y formar Gobierno. Tal vez lo que antaño se tachó de error en el art. 113 CE tenga ciertas utilidades, al menos, en semejante contexto. Ya lo anticipaba Simón Yarza en 2015: «la moción de censura constructiva podría demostrarse en el futuro, como regla eficaz para impedir la inestabilidad política» ${ }^{74}$, porque ¿alguien se imagina que, durante casi un año sin conseguir investir un presidente, tan solo seis meses después se le derribe pero sin acuerdo para elegir otro?

A lo mejor, la solución a nuestros déficits en materia de control y responsabilidad política de la acción del Gobierno no esté solo en el carácter constructivo de la censura del art. 113 CE. Este es un problema, me atrevería a decir, estructural, que necesita de más cambios que eliminar las palabras «candidato alternativo» de nuestra Norma Fundamental. Tenía razón Sole Túra cuando en la sesión de 13 de julio de 1978 calificaba a la censura parlamentaria de «problema clave con que se enfrenta el sistema parlamentario moderno» ${ }^{75}$, pero las mociones de censura no son la única forma con que se puede obligar al Gobierno a responder, como la dimisión no es la única respuesta posible.

La materialización de la responsabilidad política no puede verse únicamente reducida al mecanismo de la moción de censura, ya se la califique de «destructiva»o constructiva, pues ello sí pone en peligro el principio básico del parlamentarismo, como tampoco se la puede hacer depender única y exclusivamente del ligamen de la confianza. En realidad, este ligamen Gobierno-Congreso que supone la otorgación de la confianza no es el único medio que permite el control del Gobierno. De ello es muestra, a sensu contrario, la reciente polémica sobre si el Gobierno en funciones está también sometido al control parlamentario. Mientras que el Gobierno, lógicamente se aferraba a la inexistencia de ese ligamen, autores como Torres del Moral o Blanco Valdés sostiene lo contrario, pues aunque el Gobierno este cesante el Estado no se

72 Alzaga, op. cit., p. 523.

73 García FernandeZ, «La moción de censura en España: funcionalidad...op. cit., pp. 40 y 41.

74 Simón Yarza, op. cit., p. 108.

75 Diario de Sesiones del Congreso de los Diputados, núm. 109, pp. 4232 y 4233. 
detiene y, en consecuencia, el control a que está sujeto el Gobierno debe estar siem$\mathrm{pre}^{76}$. Esta situación demuestra que no es ese «ligamen de la confianza» lo que exclusivamente determina el principio de responsabilidad a que está sometido el Gobierno. La retirada de la confianza es uno de los modos en materializa en los sistemas parlamentarios, pero control y responsabilidad del Gobierno es una cuestión que, hoy en día, va mucho más allá que la mera constatación de que el Ejecutivo cuenta o no con una confianza, en ocasiones, algo artificial como en la XII Legislatura. Como dice Torres del Moral, la responsabilidad política que singulariza el sistema parlamentario es lo que se dilucida ante la representación de la soberanía nacional y una Constitución democrática no puede querer que haya políticos irresponsables ${ }^{77}$.

De lo que se trata es de salir de ese círculo vicioso en el parecemos seguir instalados cuarenta años después. De zanjar esa discusión estéril sobre una sola palaba «constructiva». De abandonar de una vez por todas aquel «equilibrio de debilidades» ${ }^{78}$ sobre el que pareció construirse la «censura» en España. Construyamos un Legislativo fuerte, reforzando sus posibilidades de control real del Ejecutivo, que, por ende, resultará fortalecido desde el momento en que se eliminen tentaciones de emprender políticas irresponsables o tendencialmente criminales.

\section{BIBLIOGRAFÍA}

Alzaga Villamil, Ó., "Artículo 113», en Comentario sistemático a la Constitución española de 1978, 2. 'ad., Marcial Pons, Madrid, 2016.

Alzaga Villaamil, Ó., "Artículo 112», en Comentario sistemático a la Constitución española de 1978, 2. ${ }^{\circ}$ ed., Marcial Pons, 2016.

Aragón Reyes, M., «El control parlamentario como control político», Revista de Derecho Político, núm. 23, 1986.

Bentham, J., Tratados de Legislación Civil y Penal, Editora Nacional, Madrid, 1981.

Blanco Valdés, R., ABC, 16 de mayo de 2016.

Cortes Generales, Constitución española .Trabajos parlamentarios, t. I, Cortes Generales, Madrid, 1981.

De Esteban, J. y GonZÁlez-Trevijano, P. J., Curso de Derecho Constitucional español, t. III, Servicio de Publicaciones de la Facultad de Derecho, Universidad Complutense, Madrid, 1994.

Diario de Sesiones del Congreso de los Diputados, de 28, 29 y 30 de mayo de 1980.

Diario de Sesiones del Congreso de los Diputados, núm. 109, de 13 de julio de 1978.

Diario de Sesiones del Congreso de los Diputados, núm. 161, de 26 de mayo de 2017.

Diario de Sesiones del Congreso de los Diputados, núm. 28, de 5 de abril de 1990.

76 Blanco Valdés, R., ABC, 16 de mayo de 2016.

77 Torres del Moral, «Responsabilidad política de los ministros»... op. cit.

78 Sole Tura, J. y Aparicio Pérez, M. A., Las Cortes Generales, Madrid, Tecnos, 1984, p. 211. 
Diario de Sesiones del Congreso de los Diputados, núm. 53, de 16 de mayo de 2017.

Diario de Sesiones del Congreso de los Diputados, núm. 56, de 26, 27 y 30 de marzo de 1987.

Diario de Sesiones del Congreso de los Diputados, núm.65, de 27 de junio de 2017.

Díaz Revorio, F. J., «La función de control y responsabilidad política», en «La reforma de la Constitución», dir. E. Álvarez Conde (dir.) Reflexiones y propuestas sobre la reforma de la Constitución española, Comares, Granada, 2017.

El País, 14 de junio de 2017.

García Escudero, J. M. ${ }^{a}$, «Cortes constituyentes», Ya, 5 de junio de 1977, Fundación Juan March, Archivo Linz de la Transición española (URL: http://linz. march.es/Documento.asp?Reg=r-7326).

García Escudero, P., «La regeneración del Parlamento. El papel del Congreso, el Senado y los Parlamentos autonómicos», en En pro de la regeneración política de España, dirs. E. Arnaldo Alcubilla y P. González-Trevijano, Fundación URJC/ Fundación Canal Isabel II, Madrid, 2015.

García FernandeZ, J., «La moción de censura en España: funcionalidad y ¿reforma?», Cuadernos para el debate, núm. 273-274 (agosto-septiembre), 2017.

García Fernandez, J., «Moción de censura», El País, 20 de mayo de 2017.

García Morillo, J., «La responsabilidad política», Temas Clave de la Razón Práctica, n. ${ }^{\circ} 45$ (septiembre), 1994.

GonZAlez HernANDEZ, E., «Aforamiento ante el Tribunal Supremo y responsabilidad de los empleados públicos: la diferente separación de poderes en los orígenes del constitucionalismo», Revista General de Derecho Público Comparado (Iustel), núm. 21, julio, 2017 URL: http://www.iustel.com/v2/revistas/detalle_revista. asp?id_noticia $=418909 \& d=1)$.

GonZalez Hernandez, E., «Veinticinco años de relación fiduciaria entre las Cortes Generales y el Gobierno», Revista de Derecho Político de la UNED, núms. 58/59, 2003.

Gonzalez Hernandez, E., La responsabilidad penal del Gobierno, Centro de Estudios Políticos y Constitucionales, Madrid, 2002.

GonZÁlez-Trevijano, P., La cuestión de confianza, MacGraw-Hill, Madrid, 1996.

- CIS, Estudio n. ${ }^{0} 3173$, de abril de 2017 (URL: http://www.cis.es/cis/export/sites/ default/-Archivos/Marginales/3160_3179/3173/es3173mar.pdf)

- CIS, Estudio n. ${ }^{\circ 3183}$, del CIS: Barómetro de julio de 2017 (URL: http:// www.cis.es/cis/export/sites/default/_Archivos/Marginales/3160_3179/3173/ es3173mar.pdf)

Mcilwainm, Ch. H., Constitucionalismo antiguo y moderno, Centro de Estudios Políticos y Constitucionales, Madrid, 2016.

Montero, J. R., «La moción de censura en la Constitución de 1978: supuestos constituyente y consecuencias políticas», Revista de Estudios Políticos, núm. 12, 1979.

OBREgón GARCíA, A., La responsabilidad criminal de los miembros del Gobierno: análisis del artículo 102 de la Constitución española, Cívitas, Madrid, 1996. 
Pérez-Serrano Jaureguí, N., «Crónica parlamentaria», Revista de las Cortes Generales, núm. 29, 1990.

Revista de Derecho Político, núm. 26, 1988 (URL: http://e-spacio.uned.es/fez/eserv. php?pid=bibliuned:Derechopolitico-1988-26-2331B726\&dsID=PDF).

Santaolalla López, F., Derecho Parlamentario español, Espasa, Madrid, 1990.

SEgur, P., La responsabilité politique, Presses Universitaire de France, París, 1996.

Simón YARZA, F., «La moción de censura: ¿Constructiva u «obstructiva»?, Revista Española de Derecho Constitucional, núm. 103 (enero-abril), 2015.

Sole Tura, J. y Aparicio Pérez, M.A., Las Cortes Generales, Madrid, Tecnos, 1984.

Torres del Moral, A., «Censurar ¿para qué?», El Mundo, 13 de junio de 2017.

— «Responsabilidad política de los ministros», Diario del Derecho. Iustel, (URL: http://www.iustel.com/diario_del_derecho/noticia.asp? ref_iustel =1166274)

Villoria Mendieta, M., «Transparencia y rendición de cuentas», en Desafección política y regeneración democrática en la España actual: diagnósticos y propuestas, F. Llera Ramo (coord.), Centro de Estudios Políticos y Constitucionales, Madrid, 2016.

Virgala Foruria, E., La moción de censura en la Constitución española de 1978, Centro de Estudios Constitucionales, Madrid, 1988.

VON MoHL, R., «Sobre la responsabilidad de los ministros en las Monarquías constitucionales», en enLiberalismo alemán en el siglo XIX. 1815-1848, Rotterck, Welcker, Pfizer y Mohl, Centro de Estudios Constitucionales, Madrid, $1987 .$.

Welcker, C. T., «Responsabilidad de los príncipes y los ministros», en Liberalismo alemán en el siglo XIX. 1815-1848, Rotterck, Welcker, Pfizer y Mohl, Centro de Estudios Constitucionales, Madrid, 1987.

Wences Simon, I., «Cultura de la legalidad y rendición de cuentas social», en Cultura de la legalidad. Instituciones, procesos y estructuras, eds. M. Villoria Mendieta e I. Wences Simón, Catarata ed., Madrid, 2010.

Title:

Government's model of Responsibility/Responsiveness in 1978 Constitution or playing at «seven and a half»

Summary:

I. 1978: A Constitution, without doubt, meritorious, II. From criminal responsibility to political responsibility. III. The Government's responsibility in the 1978s Spanish Constitution: A. Art. 102 and criminal responsibility, B. Political responsibility through censure: a. A forgotten 
«vote of confidence», b. The «motion of censure»: three times and no resignation, IV. The future is coming. Bibliography.

\title{
Resumen:
}

El presente paper, analiza el régimen de responsabilidad del Gobierno contenido en la Constitución española de 29 de diciembre de 1978 desde una doble vertiente. Por un lado, explica las normas constitucionales que regulan el régimen de responsabilidad gubernamental tanto jurídica como política. Por otro, centra su atención en el desarrollo de las previsiones constitucionales en los cuarenta años de vigencia de nuestra Carta Magna, comentando los supuestos más sobresalientes de juicios penales en los que se ha visto inmersos ex-miembros del Consejo de Ministros y como las «cuestiones de confianza» o «mociones de censura» que han tenido lugar en sede parlamentaria. Por último, analiza, desde un punto de vista crítico, las insuficiencias del sistema y añade propuestas de futuro.

\begin{abstract}
:
This paper analyzes the regime of government responsibility/responsiveness in the 1978 Spanish Constitution from a dual perspective. On one hand, it explains the constitutional rules that govern the regime of governmental responsibility/responsiveness, both legal and political. On the other hand, it focuses on the development of the constitutional provisions in the 40 years of our Constitution, commenting on the most outstanding cases of criminal trials in which former members of the Council of Ministers have been involved, such as «votes of confidence» or «motions of censorship» that have taken place in parliamentary seat. Finally, it analyzes, from a critical perspective, the inadequacies of the system and adding proposals for the future.
\end{abstract}

\section{Palabras clave:}

responsabilidad, gobierno, control, cuestión de confianza, moción de censura, accountability.

\section{Key words:}

responsiveness/responsability, Government, accountability, reprobation, «vote of confidence», «motion of censure» 